\title{
'Kyk hoe elk in die ander pas': Landskap, liggaam en die visuele in enkele gedigte van Johann de Lange
}

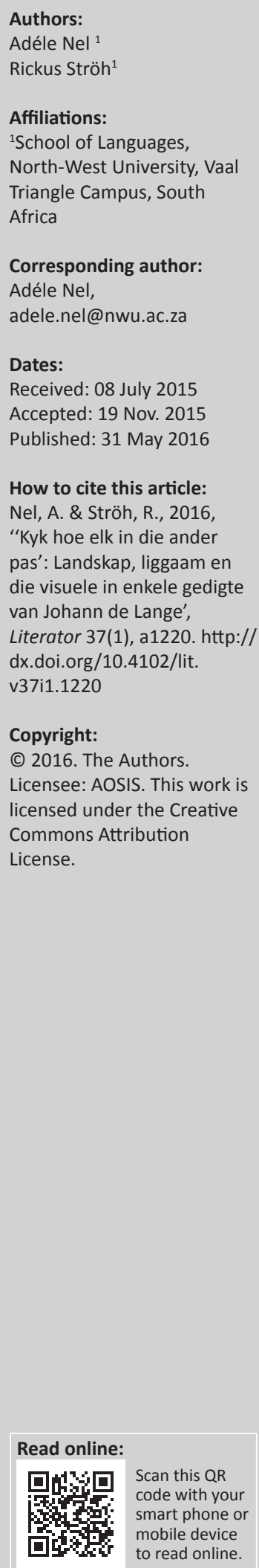

In hierdie artikel word ondersoek ingestel na die rol van landskap en die visuele in die poësie van Johann de Lange, sowel as na die verbintenis of verbondenheid tussen liggaam en landskap. Die meervoudige rol wat landskap in De Lange se oeuvre speel en die gepaardgaande visuele ingesteldheid word in enkele sleutelgedigte uit resente bundels verken en bespreek deur van relevante teoretiese konsepte (hoofsaaklik soos uiteengesit deur Wylie 2007) gebruik te maak. De Lange leun aan by die fenomenologiese denkskool vir wie visie en liggaam, liggaam en landskap ten nouste verweef is, maar ook by tendense van die nuwe materialisme en die ekologiese gedagte. Daar word gevolglik aangetoon dat die saambestaan van liggaam en landskap bowenal verband hou met relasionaliteit. Die digterlike proses en die wyse waarop landskap en liggaam as inspirasie vir die skryf van poësie dien, word ondersoek, en daar word aandag geskenk aan voyeurisme en die landskap van die erotiek.

'See how each fits into the other': Landscape, body and visual in some poems of Johann de Lange. In this article we investigated the function of landscape and the visual in Johann de Lange's poetry as well as the bond or connectedness between body and landscape. The multiple functions of landscape in De Lange's oeuvre as well as the concomitant visual disposition amongst selected key poems from recent volumes are investigated by using relevant theoretical concepts (mainly as discussed by Wylie 2007). De Lange also gleans from the phenomenological school of thought in which vision and body, body and landscape are closely interwoven. He also makes use of other trends such as new materialism and ecological thought. Consequently it is shown that the coexistence of body and landscape can be closely connected with relationality. The poetical process and the manner in which body and landscape serve as inspiration for the poetical writing are explored with special reference to voyeurism and the erotic landscape.

\section{Inleiding}

\section{Die term landskap}

Johann de Lange se sterk visuele ingesteldheid en intense gemoeidheid met die oog blyk reeds duidelik uit die voorblaaie van sy onderskeie digbundels. Met die uitsondering van sy debuutbundel verskyn daar telkens 'n kunswerk op die bandontwerp. Visagie (2015:610) verwys in hierdie verband na De Lange se beplande paratekstuele kommunikasie. Opvallend is die klem wat telkens val op die menslike, soms eksplisiet manlike liggaam (vergelyk die overte uitbeelding van manlike geslagtelikheid op Nagsweet (1991) se voorblad); of aspekte van die liggaam soos byvoorbeeld die menslike oog $^{1}$ (Die oog van die storm van die kunstenaar Judith Mason) op die voorblad van Weerlig van die ongeloof (2011); of die menslike voetspoor (Walking through the low veld, eweneens van Mason) op die voorblad van Stil punt van die aarde (2014). Op die agterblad van die laasgenoemde bundel verskyn daar 'n skets van 'n menslike hand (by implikasie skrywershand) saam met versreëls uit die gedig 'Catullus praat met die digter op Diemersdal' (De Lange 2014:27) - versreëls wat saam met die skets as parateks dien:

\footnotetext{
Vir die hart ongedurig na 'n lang seereis

wag die warmer keerkring van die palmblaar.

Digters volg die soet spoor van die rietmuis

wat ritsel oor papier. Woorde slyt teen mekaar

\& paar, rond \& glad soos kieselsteen.
}

1.In 2010 verskyn'n keur uit sy verse onder die tiltel Judasoog (2009) [Hierdie verwysing kom nie in die verwysingslys voor nie. Kan u dit invoeg asb.]. Vir Beukes (2015:591) is dit " $n$ goedgekose titel aangesien die voyeuristiese motief in sy werk vooropgestel is'. 
Hierdie versreëls aktiveer terselfdertyd verdere kenmerke van De Lange se digterskap: die kunsteoretiese besinning oor die skryfdaad en die digkuns, die erotiese tematiek, sowel as die landskap as tema. Die menslike voetspoor as parateks op die voorblad van Stil punt van die aarde dui op die digterlike spoor soos trouens reeds eksplisiet verwoord in 'Narwal' (De Lange 2012:12): 'Die digter is eweneens 'n sonderlinge dier... Hy los sy spore op papier.' Die menslike voetspoor is terselfdertyd ' $n$ indeksale teken na mens én landskap - die mens trap spore op die aarde en die aarde getuig van 'n menslike inskripsie. Daar is dus ' $n$ momentele verbintenis van mens en landskap. Reeds in 1984 verskyn die gedig 'Siklus' (De Lange 1984:35) waaruit dié vervlegting van liggaam en landskap duidelik blyk:

Die maan het nie 'n gewete nie.

Sy waaier oor my klein voetspore.

In hierdie landskap is ek sterflik.

Die maan verander alles in klip.

Ek gaan lê soos water. Soos water.

Ook in hierdie gedig is daar ' $n$ verwysing na die menslike inskripsie van 'klein voetspore' in die landskap, terwyl die vergelyking in die slotreël ' $n$ eenwording van mens en landskap impliseer - soos die sáámbestaan van grond en water op die oppervlak van die aarde.

In hierdie artikel word ondersoek ingestel na die rol van landskap en die visuele in die poësie van Johann de Lange, sowel as die verbintenis of verbondenheid van liggaam en landskap. Die reikwydte van die artikel is egter beperk in dié sin dat slegs enkele relevante gedigte (dus gedigte waarin landskap, liggaam en visie ' $n$ beduidende rol speel) uit drie resente digbundels betrek word, naamlik Die algebra van nood (2009), Vaarwel, my effens bevlekte held (2012) en Stil punt van die aarde (2014).

\section{Teoretiese raamwerk vir'n bespreking van landskap, liggaam en die visuele}

\author{
'The landscape thinks itself in me, and I am its \\ consciousness' - Paul Cezanne
}

Daar is reeds omvattend navorsing gedoen oor die aard van landskap in die (Afrikaanse) ${ }^{2}$ letterkunde. Daarom fokus hierdie artikel slegs op enkele teoretiese aspekte wat relevant is vir die lees van De Lange se gedigte. Die term landskap is egter nie 'n enkelvoudige begrip nie en kan gevolglik ook nie in 'n enkele definisie vasgepen word nie, deels vanweë die feit dat dit ' $n$ rol speel in verskillende dissiplines soos beeldende kuns, literatuur, (kulturele) geografie en antropologie. Ten einde uitsluitsel te kry omtrent die genuanseerde betekenis van landskap is dit egter wenslik om die term bondig te omskryf en die verskillende fasette daarvan uit te lig.

In sy verhelderende boek, Landscape, beweer Wylie (2007:1-11) vanuit 'n geografiese perspektief dat landskap in beginsel te

2.Dit val nie binne die reikwydte van hierdie artikel om 'n volledige weergawe van die diskoers te gee nie. make het met spanning. 'Landscape is tension' (Wylie 2007:1) is die premisse van sy redenasie. Hy wys daarop dat hierdie spanning op vier maniere manifesteer, naamlik die spanning tussen nabyheid en afstand (proximity/distance), observasie en bewoning (observation/inhabitation), oog en grond (eye/ land) en kultuur en natuur (culture/nature). Dit is dus duidelik dat die term meervoudige betekenisse dra. Wylie (2007:16) wys self ook hierop in die slot van sy inleiding deur te beklemtoon dat hierdie spannings kreatief en produktief is.

Die spanning tussen nabyheid en afstand, soos ook die spanning tussen observasie en bewoning, hou direk verband met die visuele - dit betrek 'n waarnemer én dit wat waargeneem word. Die self en die landskap is ineengestrengel en verweef; landskap is dus ' $n$ in-die-wêreld-syn (being-inthe-world). 'I am my body, which is always already both in and of the world' (Wylie 2007:149; kursivering oorspronklik). Hierdie denkwyse sluit aan by dié van die fenomenologie en spesifiek die opvattings van Merleau-Ponty $(1962 ; 1968)$ wie se uitgangspunt is dat visie en liggaamlikheid ten nouste verweef is. Hy stel onomwonde die vraag: 'Where are we to put the limit between the body and the world, since the world is flesh? (Merleau-Ponty 1968:138).

In 'n lewende, beliggaamde ervaring is visie landskap en landskap visie, en wanneer daar spesifiek na landskapkuns gekyk word, sien ons beide gelyktydig: die skilder se visie en die visuele landskap in mekaar gegrif (Wylie 2007:3). Kemp en Forster (2011:194) redeneer min of meer in dieselfde trant en huldig die volgende mening: Om die wêreld te skilder, impliseer ' $n$ blik waarvan die wêreld onbewus is (met ander woorde 'n voyeuristiese blik). 'Hierdie blik bestaan egter nie net uit die eenvoudige proses van kyk en skilder nie; die liggaam is as 't ware deel van die skilderproses' (Kemp \& Foster 2011:194). Teenoor hierdie fenomenologiese uitgangspunt is daar egter wel die denkskool vir wie die idee van landskap verwydering en observasie impliseer.

Waar die spanning tussen observasie en bewoning ter sprake is, is die opvatting dat die begrip landskap 'n manier is om die wêreld te aanskou. Ons omskryf onsself - ons bepaal die essensie van wat dit is om as ' $n$ menslike wese te bestaan - in terme van visuele selfstandigheid. Ons definieer onsself nie as wesens in 'n wêreld nie, maar as 'n gesigspunt op die wêreld; as toeskouers wat daarna kyk van 'n afstand af of van bo af (Wylie 2007:145). Daarnaas staan weer eens die opvattings van die fenomenologiese ontologie. MerleauPonty (1962) gebruik die term ineenvlegting of ineenstrengeling (intertwining) om na die verhouding tussen self en landskap te verwys en om die verweefde eenheid van beliggaamde visie maar ook landskap en liggaam te beklemtoon. ${ }^{3}$ My liggaam is beide waarnemer en deel van dit wat waargeneem word; beide subjek én objek. As synde-in-die-wêreld is landskap 'n milieu van verbintenis én betrokkenheid. Dit is 'n wêreld waarin geleef word en nie net 'n toneel om te aanskou nie. Die geograaf Ingold (2000) neem die idee verder

3.Vergelyk ook die volgende stelling: '... to look at an object is to inhabit it, and from this habitation to grasp all things in terms of the aspect which they present to it' (Merleau-Ponty 1962:68) 
en bestempel landskap as bewoning - dit is die wêreld soos dit geken word deur diegene wat daarin woon. Hy is ook van mening dat '... through living in it, the landscape becomes a part of us, just as we are part of it' (Ingold 2000:191).

Die spanning tussen oog en grond waarna Wylie verwys, blyk duidelik as die heel basiese definisie(s) van die term landskap in oënskou geneem word. Die HAT (2005:651) verduidelik landskap soos volg: 'Streek met 'n eiesoortige geaardheid' en gee die volgende as 'n voorbeeldsin: 'Ek verkyk my aan die pragtige landskap om my.' Hier val die klem reeds op die visuele - dat daar deur 'n individuele persoon na 'n landskap gekyk word. Die OSACD (2010:657) omskryf landskap as 'all the visible features of an area of land' en ook as 'a picture representing an area of countryside'. Uit hierdie basiese definisies is dit duidelik dat landskap gaan oor 'n uitbeelding van die natuur of landelike gebiede (land), wat deur iemand (oog) waargeneem word. Cresswell (2004), wat vanuit 'n geografiese perspektief werk, definieer op sy beurt landskap soos volg:

Landscape refers to the shape - the material topography - of a piece of land. This may be apparently natural (though few, if any, parts of the Earth's surface are untouched by humans) landscape or it might be the obviously human, or cultural, landscape of a city. (bl. 10)

Cresswell verwys met hierdie definisie van landskap na die beskrywing van die topografiese besonderhede van 'n gebied. Hy beklemtoon verder dat die term landskap 'n besondere geskiedenis het en betrek ook die skilderkuns, veral die opkoms van die landskapkuns, wat die visuele aard van landskap op die voorgrond stel. Landskap is dus die fenomeen self én ons persepsie daarvan. Dit is met ander woorde iets waarna gekyk word, maar dit is terselfdertyd 'n manier waarop daar na dinge gekyk word.

\section{Landskap en letterkunde}

Met verwysing na die kunsteorie dui Wylie (2007:55) voorts aan dat landskap fundamenteel visueel is. Ook Creswell (2004:10) beklemtoon dat '... landscape is an intensely visual idea'. Hy wys verder daarop dat landskap 'n fokus op die materiële topografie van 'n stuk aarde (dit wat gesien kan word) kombineer met die voorstelling van visie (hoe dit gesien word). Hierdie fokus op visie en die visualiteit van landskap word onderstreep in die meeste literatuur wat binne die kulturele geografie, kunste en geesteswetenskappe oor landskap geskryf is. Die visuele is gevolglik ' $n$ onskeibare kenmerk of eienskap van landskap, nie net in die konteks van die kunste nie, maar ook in ander vakgebiede soos die letterkunde.

Verschaffel (2012) het oor landskapkuns die volgende te sê:

[It] shows a world that can only be seen in images, and usually does not resemble what can be seen 'in reality' [or] the image of the landscape makes something visible or represents a meaning that is not visible in itself. (s.p.)

Landskap, in die konteks van die visuele kunste, is met ander woorde subjektief en in 'n sekere mate deur die kunstenaar gekodeer. Coetzee (1988:40) wys dan ook in hierdie verband na die manier waarop landskap in die letterkunde geskep of gekonstrueer word: 'Picturesque landscape is, in effect, landscape reconstituted in the eye of the imagination according to acquired principles of composition.' Hierdie 'oog' waarna Coetzee verwys, kan dié wees van die kunstenaar of skrywer, maar ook van die persoon wat die beskrywing lees en die landskap in sy of haar verbeelding probeer (her)skep. Die implikasie is dat daar op verskillende maniere na 'n landskap gekyk kan word.

Die spanning tussen kultuur en natuur handel oor natuurlike prosesse en menslike kulturele praktyke wat landskapkuns en letterkunde insluit. Wylie (2007:55) is in hierdie verband van mening dat landskap sy oorsprong in die visuele kunste gehad het en dat landskap 'n noue verband het met landskapskuns, wat opsigself 'n komplekse en diverse artistieke genre is wat veral geassosieer word met die visualisering van die verband tussen kultuur en natuur. Duckworth (1991:1015) skryf uitgebreid oor die wyse waarop landskap 'n sentrale posisie in spesifiek die letterkunde bereik het en lê klem op die estetiese en intellektuele ontwikkelinge in die agtiende eeu. Die gevolg daarvan was dat ruimte of geografiese ligging estetiese waarde begin geniet het en sodoende is die fokus op landskap geplaas. Duckworth (1991:1016) wys verder daarop dat '... literature and landscape has become a focus in recent decades for extrinsic modes of interpretation, including those of a biological or psychological or political sort'. Coetzee (1988:166) stel die volgende vraag wat (soos ook Duckworth se voorafgaande stelling) steeds vir kontemporêre Afrikaanse poësie relevant is: 'Hoe moet landskap in die poësie verstaan en interpreteer word?' (eie vertaling). Hy (Coetzee 1988) stel voorts ook die vraag na die funksie van landskap in die literatuur:

If literary landscape is not to be a secondary and inferior art, a mere verbal transcription of a scene already virtually composed, it must do, or offer to do, something that pictorial landscape cannot: read out and articulate the meaning of landscape. (bl. 166)

Hieruit blyk dit dat Coetzee meen landskap is meer as net 'n beeld wat in die letterkunde geskep word. Dit dra ook by tot die betekenis van die bepaalde literêre werk, en gevolglik kan landskap en die verkenning van die rol wat landskap in die teks speel 'n manier wees om 'n literêre teks te ontsluit. Viljoen (1998:76) sluit hierby aan deur te noem dat dit 'n uitdaging is om vas te stel hoe landskap se betekenis in die letterkunde geïnterpreteer word.

\section{Landskap en gender}

Waar die blik op die landskap ter sprake is, argumenteer Wylie (2007:85-86) dat landskap selfs ook met gender in verband gebring kan word: verskillende landskappe is gekodeer in verskillende geslagte. Die stedelike landskap word byvoorbeeld met manlikheid vereenselwig en die huislike met die vroulike. Wylie (2007:84) beklemtoon dat daar gewoonlik met 'n manlike blik na landskap gekyk word. Labbe (1998:ix) ondersteun hierdie standpunt deur te meld dat die blik (gaze) inderdaad een van die bepalende 
eienskappe van manlikheid is. Daar kan gevolglik aangeneem word dat landskap tradisioneel vanuit ' $n$ manlike perspektief aanskou en dan gerepresenteer word.

Wylie (2007:84) verskaf twee moontlike redes waarom hierdie konfigurasie tot stand gekom het. In die eerste plek is landskappe histories in die geografiese diskoers meestal gesien in terme van die vroulike liggaam en die skoonheid van die natuur. Hierdie siening hou gevolglik verband met die tradisie in die skilderkuns waar vroue gewoonlik die objek was wat geskilder sou word. In sy bekende teks, Ways of seeing, skryf John Berger (1972:47) oor dié historiese objektivering van die vrou in die skilderkuns: 'One might simplify this by saying: men act and women appear. Men look at women. Women watch themselves being looked at' (kursivering oorspronklik). Hierdie tradisionele representasie van die (meestal naakte) vroulike liggaam plaas die vrou as vertoonstuk vir die voyeuristiese plesier van die manlike toeskouer, met die gevolg dat die gerepresenteerde vroulike liggaam as 'n verbeelde erotiese objek vir die manlike blik aangebied word.

Ten opsigte van die landskapkuns verduidelik Verschaffel (2012) voorts:

Every image excludes the viewer and turns him into a beholder, but in the image of the landscape, he is actually invited to take his place there as a distant beholder. (s.p.)

Die opvatting dat landskap as vroulik beskou kan word, het volgens Wylie (2007:84) seksuele konnotasies tot gevolg, in dié sin dat die vroulike liggaam-as-landskap deel vorm van 'n metaforiese topografie van begeerte. Dit sluit aan by die manlike blik op die landskap of liggaam, die bewondering daarvan en die besit van die landskap of die vroulike liggaam.

Die tweede rede wat Wylie (2007:84) verskaf waarom landskap met gender in verband gebring kan word, verwys na die onderskeid tussen verstand (mind) en liggaam (body): 'This separation, fundamental to the Western scientific tradition detached observation, frees the masculine gaze of geographers upon the landscape from any sensual, fleshy association.' Alhoewel hierdie siening die landskap van geslag probeer vrymaak, is daar steeds die problematiek van plesier wat verkry word deur met spesifiek 'n manlike blik na die landskap te kyk. Die plesier van kyk word deur Duckworth (1991:1017) verduidelik in terme van ons onbewuste erkenning van die toneel se beskikbaarheid vir seksuele, orale, koesterende en eliminerende praktyke. Verder noem hy ook dat hierdie hunkering na die landskap aanleiding kan gee tot die begeerte om die landskap te betree of te besit.

Die vraag ontstaan nou hoe die vroulike blik op die landskap of liggaam daar uitsien. Om hierdie vraag te antwoord, probeer Nash (1996) in haar artikel (vanuit 'n feministiese oogpunt) om die opvatting dat landskap in terme van die vroulike liggaam gesien word, te kritiseer en te ondermyn, en betrek sy kwessies van landskap, gender en die visuele. Sy gebruik as voorbeeld 'n foto, getiteld Abroad, van die kunstenaar Diane Bayliss wat die naakte torso van 'n man uitbeeld teen 'n agtergrond van wolke en blou lug, in die styl van 'n landskap. Abroad is 'n beeld wat die normatiewe kulturele dualiteite ondermyn waarvolgens manlikheid gekodeer word as aktief en waarnemer, terwyl vroulikheid gekodeer word as passief en waargenome. Nash (1996) argumenteer voorts:

... the politics of representation or visual pleasure can be assessed by reference to a male or female gaze, it is more useful to think of a multiplicity of shifting viewing positions, gazes, or ways of seeing. (bl. 159)

Dit beteken dat die manlike en/of vroulike liggaam vir sowel mans as vroue visuele plesier kan verskaf.

\section{Landskap en liggaam in die poësie}

Viljoen (2009) sowel as Smith (2015) bring 'n verdere aspek na vore waar landskap ter sprake is, naamlik die verband tussen liggaam en landskap in die poësie - 'n aspek wat óók relevant is vir die lees van De Lange se digkuns. Volgens Viljoen (2009:98) maak Antjie Krog gebruik van die liggaam as metafoor vir poësie en vir landskap, maar ook omgekeerd dien landskap as liggaam. Die verweefdheid van landskap en liggaam is egter nie net tot die letterkunde beperk nie. Van Alphen (1998:144) skryf byvoorbeeld van Vincent van Gogh se skilderkuns ${ }^{4}$ die volgende: 'Van Gogh's equal treatment of body and space turns the body into a landscape. ... The landscape is in fact a bodyscape.' Hierdie verweefdheid of wisselwerking tussen landskap en liggaam kan vanuit verskillende invalshoeke beredeneer word. Die opvattings van die fenomenologiese ontologie, soos reeds kortliks uiteengesit, is belangrik in hierdie verband. In 'n insiggewende artikel, 'Plek as liggaam en liggaam as plek. Tendense van die nuwe materialisme en interaksie tussen mens en plek in enkele tekste uit Verweerskrif (2006) van Antjie Krog', skryf Smith (2015) oor die verbondenheid van liggaam en plek. Sy skryf vanuit opvattings van die nuwe materialisme om die verweefdheid of interaksie tussen mens en plek te beredeneer. Smith (2015:4) gebruik as uitgangspunt Iovino (2012) se argument dat '... materiële dinge, hetsy menslik of niemenslik, lewend of nielewend, onherroeplik met mekaar verweef is en verskynings is waarvan die bestaan en betekenis met die diskursiewe dimensie verbind is'. Sy sluit verder ook aan by die ekologiese gedagte in haar ontleding van Krog-gedigte, naamlik dat alle materie, menslik en niemenslik, interaktief verbind is en altyd sáám bestaan. 'Want ekologie gaan by uitnemendheid oor saambestaan; bestaan is altyd sáám bestaan' (Smith 2015:5).

In Die ander een is ek ('n titel wat reeds verbintenis impliseer) gebruik T.T. Cloete (2013) die term transendering en skryf soos volg:

Die liggaam kan hom- of haarself oordra in ' $\mathrm{n}$ ander mens óf ding, ons kan die self ekstern transendeer in 'n ander self, in 'n ander sigbare en tasbare liggaam, 'n ander bestaansvorm, of dit ' $n$ ander mens of ' $n$ ander ding soos ' $n$ dier of ' $n$ totaal gefantaseerde ding is. (bl. 221; kursivering oorspronklik.)

4. 'Van Gogh paints his body in his self-portraits as if his body were a landscape' (Van Alphen 1998:144). 
En verder: 'Ons kan deur selftransendering nie net van diere en plante nie, maar selfs van anorganiese dinge besit neem' (Cloete 2013:221). Vir Cloete is (self)transendering ' $n$ voorvereiste vir die kuns, met ander woorde spesifiek ook vir die digkuns. Hy is verder van mening dat ons deur selftransendering ons eenmalige lewens vermenigvuldig en vier, en hierdie selfvermenigvuldiging vind met name in die gedig plaas (Cloete 2013:58).

Hierdie onderskeie ooreenstemmende sieninge (hoewel vanuit verskillende invalshoeke beredeneer) oor die verweefde verhouding van liggaam en landskap, menslik en niemenslik, hou uiteindelik óók met die begrip relasionaliteit verband. Oor hierdie begrip is daar in die onlangse verlede heelwat geskryf. ${ }^{5}$ Die tese waarvandaan Silverman se teoretiese besinning van relasionaliteit in Flesh of my flesh (2009) byvoorbeeld uitgaan, is die feit dat sterflikheid die mees omvattende en deurslaggewende eienskap is wat die mens met elke ander wese op aarde deel. Cloete (2013:11) bring relasionaliteit met transpersoonlike belewenisse en die alles-samehangende werklikheid in verband. Samevattend gaan relasionaliteit dus oor verband en samehang en menslike verbondenheid of verwantskap, én wil ons daarby toevoeg: ook verbondenheid van mens en natuur, mens en landskap. Volgens Iovino (2012) se opvatting lyk dit soos volg:

New materialisms makes even more evident the fact that there is a structural interplay between the human and nonhuman, and that this interplay produces meanings which are socially relevant. ... Human corporeality, in all its material fleshiness, is inseparable from 'nature' and 'environment. (bl. 136-137)

Iovino (2012) maak verder ook die volgende relevante stelling:

The ethics implied by this perspective emphasizes that the relation between human beings and the nonhuman world is not one between an 'internal' self and an 'external' place, but rather a complex and unitary field of existence. (bl. 138)

Met voorgenoemde aspekte as agtergrond word verskillende fasette van landskap, liggaam en die visuele, soos dit in enkele gedigte van Johann de Lange voorkom, in die volgende afdelings bespreek.

\section{'n Verkennende blik op landskap, die visuele en die digterlike proses}

In sy resensie oor Vaarwel my effens bevlekte held maak Beukes (2012) die volgende uitspraak:

Binne die konstruksie van sewe afdelings is die voortstu vanaf besitterskap en verkenning van die landskap in die gedigte oor diere, landskappe en mense die afskeidsverse wat die broosheid van die menslike liggaam en psige byna tasbaar verken. (bl. 180)

Hierdie besitterskap en verkenning van die landskap kom tot stand deur aspekte van die visuele wat ' $n$ beduidende rol in De Lange se poësie speel en sluit uitbeeldings van landskap

5.Kyk na Butler (2006), Cloete (2013), Glissant (1990), Linde 2014, Nel (2012a; 2012b) en Silverman (2009). of plek sowel as die liggaam in, maar ook die verhouding tussen landskap en die digproses. In die selfrefleksiewe openingsgedig van die bundel Stil punt van die aarde (De Lange 2012:9) word die digproses dan ook in terme van landskap beskryf:

Woorde
Most important is to be able to enter a word
Ted Hughes
Gaan elke woord binne
soos 'n kontinent
sê 'n digter. Behoedsaam,
vol verwondering \& oop
vir nuwe horisonne,
navigeer die foutlyne
tussen woorde, kyk
hoe elk in die ander pas,
teen mekaar beur
$\&$ steil paradokse lug-
waarts stu: 'n Alp of 'n Andes piek na piek
opstoot uit 'n oer-oseaan.
Woorde is my kontinent,
\& poësie is my republiek.

Met hierdie gedig word daar eksplisiet oor die aard en ontstaan van die poësie bespiegel. Reeds in die openingsreëls word teks (elke woord) en landskap ('n kontinent) ${ }^{6}$ deur middel van die vergelykingskonstruksie beklemtoon en verder benadruk deur die intertekstuele verwysing na die voorgangerdigter Ted Hughes as motto. Hambidge (2014:s.p.) verwys na die slotreëls as ' $n$ '... belangrike mantra in die digkuns van De Lange waarin die wóórdgevoelige digter telkens die be-teken-isse van woorde ontsluit en nuut maak'. Dié digterskap behels volgens Bennett (2012:8) ook '... dat 'n digter deur die ontdekkingsreis van taal beweeg en sy koördinate instel om 'n gedig te skryf'. Taal word met landskap vergelyk en dit is vir die digter noodsaaklik om deur dié landskap te reis om by 'n gedig uit te kom. Hierdie verkenning bevat reeds verskeie fasette van die tradisionele sieninge oor landskap. In die eerste plek gaan dit om besit wat reeds 'n politieke ondertoon impliseer - die landskap word vir die self toegeëien. Die digter, op soek na 'n vers, gaan op 'n byna koloniserende wyse elke woord 'binne' gelykstaande aan die wyse waarop van 'n kontinent of landskap besit geneem word. Dit is opvallend hoe "n kontinent' in reël 2 verander na 'my kontinent' in die slotstrofe, wat daarop dui dat die digter oor die woorde of landskap eienaarskap neem soos die koloniseerder met die landskap doen. Die slotreël, 'poësie is my republiek', bevestig as poëtikale uitspraak ook besitterskap met gepaardgaande politieke ondertone - binne hierdie landskap of kontinent berus die oppergesag by die woord.

Die verwysing na 'horisonne' in reël 5 stel die visuele op die voorgrond. Die digter gaan die kontinent van die woord binne ten einde die landskap van die poësie te verken: hy navigeer 'die foutlyne/tussen woorde' en 'kyk/hoe elk in die 
ander pas'. Benewens die horisontale blik is daar ook 'n vertikale perspektiwiese gerigtheid, 'n uitreik vanuit die aardse na die hemelse: 'steil paradokse lug-/waarts stu: 'n Alp of Andes piek na piek'. Die verwysing na die 'opstoot uit 'n oer-oseaan' impliseer selfs 'n katabatiese blik en roep die sfeer van Genesis op; dit bied met ander woorde'n perspektief op die oeroorsprong van dinge. Die visuele in die gedig het gevolglik 'n verdere, wyer implikasie as bloot net die van sien: dit hou naamlik direk verband met landskap in die gedig, en dit is 'n aanduiding hoe integraal die oog in De Lange se poësie funksioneer.

\section{Landskap, liggaam en visie}

In Vaarwel, my effens bevlekte held (2012:30) kom die tweereëlige vers, 'Kroonden' voor:

\section{Kroonden \\ Die kroonden lê omgeval \\ beenwit grynswit in die son.}

Met die eerste oogopslag is hierdie vers oënskynlik bloot 'n gedig wat 'n toneel beskryf waarin 'n kroon- of sambreeldenneboom omgeval het en besig is om in die son te vergaan. Snyman (2012) redeneer die '... woorde in De Lange se werk "beteken" nie net nie, dit "be-teken" ook, en sodoende kom daar telkens nuwe betekenisse uit die verse'. Daar kan dus meervoudige betekenisse aan die skynbaar eenvoudige versreëls geheg word.

'Kroonden' sluit aan by die tematiek van die bundel wat Bennett (2012:8) beskryf as gedigte wat met afskeid en verlies te doen het. In die titel van die bundel word daar verwys na die afskeid van 'n 'held', maar dié held is oop vir interpretasie. In hierdie gedig kan die sterflike natuurding bestempel word as die moontlike gevalle held wat besig is om in die son te vergaan. Volgens Chevalier en Gheerbrant (1996:754) is die denneboom in die Verre Ooste egter 'n simbool vir onsterflikheid vanweë die feit dat dit ' $n$ immergroen boom is, asook vanweë die onverganklike aard van die hars. In die klassieke mitologie word die denneboom boonop ook 'n simbool vir die liggaam van 'n gestorwe god wat weer lewend geword het (Chevalier \& Gheerbrant 1996:756). Die goddelike of koninklike wat met 'held' verband hou, word voorts deur die woordkomponent 'kroon' in die titel bevestig. Ten spyte van die 'onsterflikheid' van die simboliek betreffende die denneboom, beklemtoon die gedig egter die sterflikheid van die natuurding.

In 'Kroonden' word die boom boonop gepersonifieer met die gebruik van die woorde 'beenwit' en 'grynswit' - 'n verwysing na bene van 'n gestorwe dier of mens wat deur die son wit verbleik word. Die personifikasie word verder gevoer met die beeldspraak 'grynswit' (reël 2) wat dui op 'n grynslag met wit tande. Die HAT (2005:347) verduidelik dat 'gryns' 'n trek op die gelaat is wat effens soos 'n glimlag lyk en as 'n teken van spot, hoon of haat verstaan word. Hierdie eienskappe word alleenlik by mense aangetref, wat gevolglik die boom tot menslike status verhef en die interpretasie versterk dat die gevalle kroonden as gevalle held gelees kan word. Die boom (as integrale deel van landskap) word hier met sekere dele van die liggaam vereenselwig om die weerloosheid en verganklikheid van sowel natuur as mens, landskap as liggaam te beklemtoon, en terselfdertyd word afskeid en verlies bevestig. Daar kan in hierdie verband selfs verwys word na Silverman (2009) se opvatting van relasionaliteit op grond van mortaliteit. Hier is relasionaliteit egter nie gebaseer op die sterflikheid van mens en mens nie, maar op die sterflikheid van mens én natuurdinge.

In De Lange se verse lok landskap soms sterk emosies uit, soos in die geval van die volgende gedig. In 'Dagdroom' (De Lange 2012:86) word die 'ek' in die topografiese landskap geplaas wat die verhouding tussen die kyker of spreker en landskap vooropstel - die landskap word hier nie slegs waargeneem nie, maar dit dien terselfdertyd as metafoor vir die spreker se emosionele belewing:

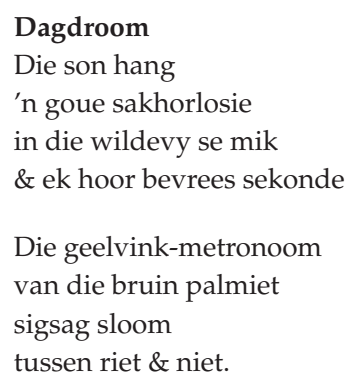

Die verband tussen landskap en liggaam, landskap en die visuele word reeds deur die titel uitgehef, want 'droom' dui op 'n beskoulike of konseptuele manier van kyk. Belangriker egter is die feit dat die droom op ' $n$ intens persoonlike blik dui. Die titel staan egter ook in 'n paradoksale verhouding tot die semantiese strekking van die gediginhoud. 'Dagdroom' word naamlik deur die HAT (2005:141) beskryf as 'nuttelose dinkery oor aangename dinge', terwyl die emosionele belewing van die spreker in die gedig die betekenis van die tweede komponent (aangename dinge) ondermyn.

In hierdie twee kwartyne word 'n laatmiddaglandskap aanskou én die sensoriese interaksie van liggaam en landskap beleef. Smith (2015:21) se siening is veral relevant as sy betoog dat dit veral die visuele persepsies van plek (lees landskap) is wat '... dien as primêre toegang tot die liggaam van plek, wat die draer is van die beliggaamde fyngevoelighede van plek'. Afgesien van die visuele waarneming word klank sintuiglik waargeneem deur middel van terme wat met tyd geassosieer word, naamlik 'tik', 'metronoom' en 'sigsag'. Die natuurlandskap word ook met tyd vereenselwig deur die metafoor van die son wat (soos) 'n sakhorlosie in die wildevy se mik hang en die geelvink wat as die metronoom optree. Beide dui op die meedoënlose verbygaan van tyd en sluit aan by die tema van verganklikheid in die bundel. Die sprekende ek hoor hoe die metaforiese sekondes tik, wat aanleiding gee tot sy eie vrees vir die onverbiddelike verganklikheid en die dood. Visagie (2015:599) wys dan ook op De Lange se volgehoue 'fassinasie met die dood' in sy digterskap. 7 Indien die komponent

7.Kyk ook in hierdie verband na Hambidge (2013). 
'nuttelose dinkery oor aangename dinge' van die titel 'Dagdroom' ten slotte in berekening gebring word, verkry die gedig 'n berekende ironiese ondertoon, want vir die mens (soos vir die natuurdinge) word verweer en sterflikheid vanweë die onverstoorbare voorttik van die tyd vooropgestel. Boonop intensiveer die 'niet' as ruimtelike kristallisasiepunt in die klimaktiese verseindreël die doodsbewustheid van mens én natuur. Hier is dus weer eens sprake van relasionaliteit op grond van sterflikheid op grond van die interaksie tussen liggaam en landskap soos inderdaad in die gedig geskied. In hierdie gedig word die spreker by implikasie in die landskap geplaas sodat hy of sy die natuurelemente soos die son en die boom sien en ook die klanke hoor wat met tyd vereenselwig word. Daar is gevolglik selfs bevestiging van transendering (op grond van personifikasie) van landskap en mens.

\section{Voyeurisme en die landskap van die erotiek}

Die opvatting dat die liggaam beide waarnemer en dit wat waargeneem word, beide subjek en objek is, bewerkstellig 'n verdere spanningsverhouding in talle gedigte. Boonop baan die objektivering van die liggaam en/of landskap die weg vir belangrike temas in De Lange se oeuvre, onder andere die uitbeelding van die voyeuristiese kyk op die liggaam en die sterk fokus op die visuele. Beukes (2006:252) wys tereg daarop dat voyeurisme ' $n$ vooropgestelde tema in De Lange se werk is en dat die oog in hierdie geval 'n kode is wat raakgelees moet word. Kemp en Forster (2011) ondersoek indringend die verskillende vorme van voyeurisme in De Lange se poësie met die klem op sy gedig 'Olympia' en maak die belangrike stelling waarmee akkoord gegaan word:

Die hipotese grondliggend aan hierdie artikel is dat die voyeurisme 'n onmisbare rol speel in die skryf- en leesproses. Nie net is die skrywer, of die digter, die voyeur wat die wêreld afloer en in die teks be-teken nie, maar sowel die teks as die leser is betrokke in en by ' $n$ verweefdheid van voyeuristiese handelinge. (bl. 189)

Hambidge (2009:28) is op haar beurt van mening dat in Johann de Lange se oeuvre konvensionele genderpatrone omgekeer word: 'Hier tref ons 'n man as kyker, as voyeur, aan wat 'n ander man (dikwels anoniem) tot seksuele objek verklaar.'

Die sterk visuele aard van die uitbeelding, en die begeerte wat dit as gevolg van die skoonheid van die manlike liggaam ontlok, het dan inderdaad 'n voyeuristiese blik of skopofilie tot gevolg. Hayward (1996:305) wys daarop dat die term skopofilie letterlik beteken 'die begeerte om te sien'. Die term het oorspronklik in die sielkunde ontstaan. Freud verduidelik dat teorieë wat met skopofilie te make het, gesentreer is rondom voyeurisme en die begeerte om te kyk na die erotiese en die verbode, en hierdie begeerte is gewoonlik rondom die manlike gesentreer (Nelmes 2003:251). Theron (1989:318) verwys na voyeurisme as 'n 'versteuring' en is van mening dat dit gedefinieer kan word as '... die doelbewuste afloer van persone (gewoonlik vreemdelinge) wat naak is, besig is om te ontklee, of wat seksueel verkeer'. Theron (1989) verduidelik ook verder dat die proses van afloerdery geskied sonder dat die persoon of persone wat afgeloer word daarvan weet:

Die seksuele stimulering wat die gedrag meebring, word verhoog omdat diegene wat afgeloer word nie daarvan bewus is nie, en die voyeuris voortdurend daarvan bewus is dat hy die risiko loop om gevang te word. (bl. 318)

Hierdie risiko is dan ook een van die dryfkragte van voyeurisme, te same met die begeerte om te kan kyk, want soos Theron (1989:318) uitwys, ervaar 'n voyeur geensins opwinding as sy maat vir hom ontklee nie - dit is juis die risiko wat die opwinding verskaf.

In die gedig, 'Haarsny', (De Lange 2014:66) word die landskap van die manlike liggaam op voyeuristiese wyse verken, terwyl die volwasse digter die jeugdige erotiese begeerte sintuiglik beskryf.

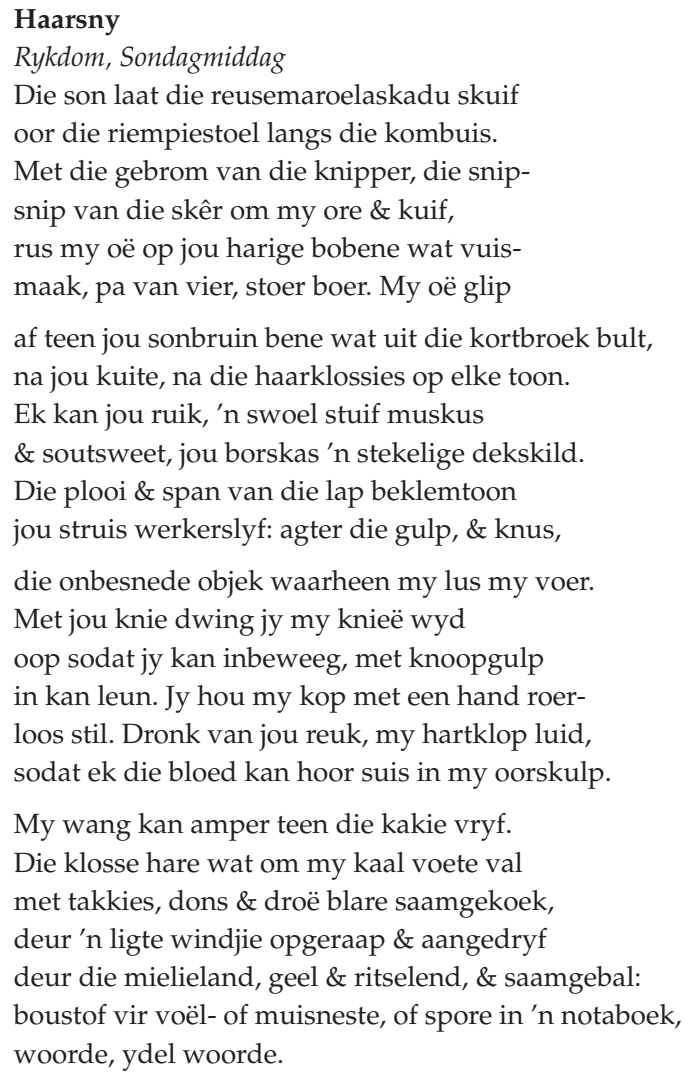

In hierdie gedig is twee gestaltes dominant: die heteroseksuele vader en die homoseksuele seun. Cloete (1984) wys op die multivalensie van die literêre gestalte en maak dié uitspraak:

... in die organiese wêreld van die literêre teks bring die gestalte ons direk uit by die hele problematiek van interpretasie, wat die direkte gevolg van die literêre meerduidigheid in vele vorms is. (bl. 43)

Die intieme nabyheid tussen die twee manlike gestaltes met teenoorgestelde seksuele oriëntasies skep seksuele spanning, soos in reëls 14 en 15 waargeneem kan word, maar dwing ook die leser, as voyeuristiese waarnemer, tot interpretasie. 
Die inset van die gedig is opmerklik ruimtelik met die implisiete verwysing na landskap in die openingsfrase van die gedig: 'Die son laat die reuse maroelaskadu skuif/oor die riempiestoel langs die kombuis.' Hierdie verwysing na landskap word aangewend om die fokus vanaf die wye natuurruimte (waarvan die son en reusemaroelaskadu indeksale tekens is) na die intieme ruimte van menslike habitat, waar die hare gesny word, te verskuif. Uiteindelik handel die gedig egter eerder oor die liggaam-as-landskap. Die fokus van die gedig is gestaltematig op die vaderfiguur wat in tradisionele kodes van patriargale manlikheid beskryf word: 'harige bobene wat vuismaak', 'pa van vier', 'stoer boer', 'struis ${ }^{8}$ werkerslyf'. Die waarnemer in die gedig is die seun wat die manlike liggaam van die vader op voyeuristiese wyse tot erotiese liggaam objektiveer en sodoende (kan 'n mens by voorbaat redeneer) die historiese objektivering van die vroulike liggaam deur die manlike blik dekonstrueer.

In versreël 5 word daar klem gelê op die spreker se oë wat op die manlike liggaam voor hom se bobene rus. Die vertikale (afwaartse) kyk word beskryf soos die blik 'af glip' teen die bene na benede. Die enjambement wat tussen strofe 1 en 2 voorkom, beklemtoon hoe die blik van die bobene na benede beweeg, net soos die leser se oë ook met die lees van die gedig vertikaal na onder beweeg. Die visie daal verder tot by die figuur se tone in reël 8. Hierna beweeg die blik opwaarts tot dit op die 'onbesnede objek', die objek van begeerte, fikseer. Die vader se bedekte penis word hier deur die oog van die verbeelding waargeneem; dus bly dit 'n droomobjek, 'n (verbode) verbeelde objek van begeerte. 'n Mens sou waarskynlik hierdie versreël meervoudig kon interpreteer. Enersyds handel dit bloot oor die ontwaking van die jeugdige erotiese begeerte. Vir Hambidge (2014) verbeeld dié gedig 'met 'n Brokeback mountain-agtige plaasagtergrond' dan ook jeugdige begeerte uiters ontroerend. Andersyds is hier sprake van ' $n$ taboe-element wat herinner aan Freud se Oedipuskompleks, maar in hierdie geval is die erotiese begeerte nie na die ouer van die teenoorgestelde geslag nie, maar na die ouer van dieselfde geslag. Daar is dus as't ware sprake van 'n dubbele taboe. Van Alphen (1998:177) skryf verhelderend oor die diskoers rondom manlikheid as kulturele konstruk met betrekking tot die skilderkuns van Francis Bacon en verwys ook na die Oedipus-verhaal. Sy siening kan terselfdertyd betrek word in'n poging tot interpretasie van die problematiese vader-seun-verhouding in De Lange se gedig. In die Oedipusnarratief is daar naamlik sprake van 'n dubbele opdrag wat aan die manlike kind opgelê word: die seun moet met die vader identifiseer ten einde sy eie seksualiteit te vorm, maar terselfdertyd word hy nie toegelaat om soos die vader te wees ten opsigte van die vader se seksuele voorregte en mag nie. Vader en seun is dus sowel kamerade as mededingers. In De Lange se gedig is die vader se genitalieë (penis as fallus) 'n aanduider van die konstruksie van patriargale manlikheid en mag (volgens heteronormatiewe opvattings), en hy is boonop die aktiewe gestalte wat liggaamlik dikteer: 'Met jou knie dwing jy my knieë wyd/oop sodat jy kan inbeweeg, met die landskap. knoopgulp/in kan leun.' Hierdie versreëls eggo coitus tussen man (aktief) en vrou (passief). Die seun identifiseer op omgekeerde wyse met die vroulike en die moeder en sy seksualiteit word dienooreenkomstig gevorm. Sy homoërotiese begeerte na die vader is gevolglik 'n oortreding en 'n ondermyning van die patriargale orde.

Ten slotte is daar in die laaste strofe 'n beskrywing van die hare wat op die grond val en met takkies, blare en stokkies meng. Dit is dus 'afvalprodukte' van sowel mens as natuur watgeïnterpreteer kan word as diesimboliese vereenselwiging van die liggaam met die landskap as dit uiteindelik deur die wind na die groter landskap van die mielieland aangedryf word. Die visuele is egter nie die enigste manier waarop die liggaam ervaar word nie. Daar word deurgaans in die gedig verwys na ander sintuiglike waarnemings wat seksuele opwinding beskryf: die klank van hartklop en bloed, asook die liggaamsreuk in reëls 9 en 10 en die amperse tasbaarheid van die liggaam in reël 19. Hierdie sintuiglike waarnemings, tesame met die visuele, beklemtoon die landskap van die liggaam sowel as die landskap van die erotiek. Grense tussen liggaam en landskap word opgehef: die gedig eindig met die uitbeelding van menslike en natuurlike 'afvalmateriaal' wat 'saamgebal' word (weer eens 'n meervoudige implisiete homoseksuele verwysing, soos ook die assosiasiespel van 'voël- en muisneste') met ironiese vrugbare gevolge: dit gee boustof vir die ontstaan van die gedig, vir 'spore in 'n notaboek' of 'spore op papier' (De Lange 2012:12), met ander woorde 'n taallandskap. Die slotreël, 'woorde, ydel woorde', word uitgehef as gevolg van tipografiese isolasie en beklemtoon só die ontstaan van die gedig as taallandskap. Die gebruik van die woord 'ydel' is opvallend omdat die HAT (2005:1408) dit enersyds omskryf as 'doelloos, vrugteloos, en sonder grond' en andersyds as 'onbeduidend, ledig, ligsinnig, sonder enige nut'. Op semantiese vlak dui die slotreël moontlik daarop dat hierdie jeugdige ervaring onvervuld en vrugteloos gelaat is ten opsigte van die seksuele begeerte, maar insgelyks wel vrugtevol was omdat die ervaring as inspirasie vir 'n gedig gedien het. Terselfdertyd word die waarde van die gedig egter gerelativeer.

In die gedig 'Aan 'n onbekende baaier' (De Lange 2009:76) word die visuele weer eens vooropgestel en is daar nogmaals eksplisiet sprake van 'n voyeuristiese kyk. Die manlike figuur word waargeneem in 'n seelandskap by Graaff se poel, 'n swemplek vir spesifiek mans in Seepunt, en tekstueel in 'n gedig vasgevang.

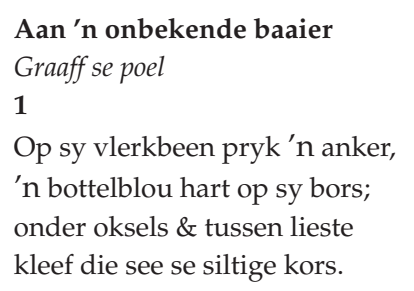

Die verwysing na die 'onbekende baaier' in die titel van die gedig dui reeds daarop dat die gedig vanuit 'n voyeuristiese perspektief geskryf is. 'Onbekende' is dan ook'n sleutelwoord omdat die onbekendheid en anonimiteit van die persoon in 
die visier juis plesier aan die digter of voyeur verskaf. Boonop is dit ook 'n afstandsaktiwiteit wat volgens Kemp en Forster (2011:185) in ooreenstemming met een van die wesenskenmerke van die voyeurisme is. Hier word die liggaam ook geteken as verbonde aan die landskap - die beskrywing van die gestalte in die gedig as 'baaier' in plaas van 'swemmer' suggereer reeds dié verbondenheid aan die landskap van die baai waarin hy waargeneem word. In die slotreël word die liggaam weer eens landskap en die landskap liggaam. Die woorde 'kleef' en 'kors' (wat óók aardkors resoneer) word naamlik uitgehef deur alliterasie en bevestig so klankmatig die 'verkleefdheid' van die liggaam en die landskap. Die natuur of see 'kleef' ook spesifiek aan die erotiese sones, die 'oksel' en 'lieste', wat die begeerte om te kyk na die erotiese en dit wat verbode is, beklemtoon.

Die see as erotiese landskap en die liggaam as landskap van die erotiek kom ook ter sprake in 'Branding' (De Lange 2014:70):

\section{Branding \\ Daar is golwe wat soos heupe beuk \\ \& wit vreugdes oor bruin rotse breek}

Landskap word in die gedig op so 'n manier beskryf dat dit terselfdertyd 'n uitbeelding is van 'n sekstoneel tussen twee mans. ${ }^{9}$ Hoewel daar geen eksplisiete bewyse van geslag in die gedig voorkom nie, word die seksuele reeds in die eerste reël gesuggereer met die woord 'heupe'. Die beweging van die golwe wat 'beuk' op die rotse voer die seksuele metafoor verder. Die beweging van die golwe word met hierdie beweging letterlik uitgebeeld, maar dit kan ook metafories gelees word vir die beweging van die seksdaad. Die natuurlike landskap word verder in die gedig beskryf as branders wat wit oor bruin rotse breek. Die seksuele metafoor kom egter ook in hierdie slotreël voor met die beskrywing van 'wit vreugdes' wat moontlik op semen na afloop van die seksuele daad kan dui. Die landskap in hierdie gedig word dus uitgebeeld as verteenwoordigend van die manlike geslag, en ondermyn so die tradisionele siening van die landskap as vroulik soos Wylie (2007:84) uitwys. Uiteindelik word die landskap in hierdie gedig tot so 'n mate gepersonifieer dat dit 'n direkte metafoor word vir die liggaam: landskap as liggaam en liggaam as landskap.

'Branding' tree terselfdertyd in gesprek met'n voorgangergedig getiteld 'Aars poetica' (De Lange 1991:92) met die motto 'vir $\mathrm{DJO}^{\prime}$ - daar is met ander woorde ook 'n gesprek met 'n voorgangerdigter en 'n verwysing na 'n poëtikale Oppermangedig. Van De Lange se gedig sê Hambidge (2009) die volgende:

Deur kruheid op sigself aan te bied as poëtika, word die seksuele nuut beskou ... Hierdie oortreding van die patriargale orde kom duidelik na vore in die gedig 'Aars poetica', opgedra aan D.J. Opperman, waarin die wet van die vader (as kastreerder en beheerder van orde in Lacan se terme) en die poëtiese wet van die vader (as kanoniseerder en simbool van die metaforiek) verseksualiseer word. (s.p.)

9.Vergelyk Paglia (1990:3) se stelling: 'Sex is the point of contact between man and nature, where morality and good intentions fall to primitive urges. I call it an intersection.
In dié gedig word die letterlike seksuele begeerte na die 'vader' in dieselfde beeldspraak as in 'Branding' verwoord:

$$
\begin{aligned}
& \text { Ek het jou opgetel } \\
& \text { en deur die smal } \\
& \text { geswolle poort } \\
& \text { die warm skuit } \\
& \text { gestoot } \\
& \text { tot jy blink } \\
& \text { gebeuk het } \\
& \text { soos die see } \\
& \text {... (Ons kursivering.) }
\end{aligned}
$$

Hambidge (2009:29) wys dan ook tereg daarop dat Opperman se ars poetica hier geapproprieer en bloedskendig 'vermink' word. Daar is dus sprake van oortreding én betreding, 'n erotiese begeerte na die liggaam én die gedig wat beide metafories verbind word aan die landskap van die erotiek.

\section{Ten slotte}

Die doel van hierdie artikel was om landskap en liggaam en die gepaardgaande visuele ingesteldheid in enkele sleutelgedigte uit resente bundels van Johann de Lange te verken en te bespreek deur van relevante teoretiese konsepte (hoofsaaklik soos uiteengesit deur Wylie (2007)) gebruik te maak. Uit hierdie ondersoek blyk dit duidelik dat landskap 'n meervoudige rol in De Lange se oeuvre speel. De Lange leuen aan by die fenomenologiese denkskool vir wie visie en liggaam, liggaam en landskap ten nouste verweef is, maar ook by tendense van die nuwe materialisme en die ekologiese gedagte. Hierdie saambestaan van liggaam en landskap hou bowenal met relasionaliteit verband.

Die landskap dien dikwels as inspirasie vir die skep van verse. Boonop is die visuele ten nouste aan landskap én liggaam verbind, en deur die verskillende maniere van kyk, wat op sowel landskap as die liggaam van toepassing is, kom die gedig tot stand. Die manlike liggaam as landskap, maar ook landskap as liggaam, word telkens in De Lange die gedigte uitgebeeld, en dit sluit onder andere die landskap van die erotiek in.

\section{Erkennings}

Hiermee word die finansiële bydrae van die Nasionale Navorsingstigting (NRF) en die Noordwes-Universiteit (NWU) erken.

\section{Mededingende belang}

Die outeurs verklaar dat hulle geen finansiële of persoonlike verhouding(s) het wat hulle op 'n onvanpaste manier in die skryf van hierdie artikel kon beïnvloed het nie.

\section{Outeursbydraes}

R.S. het die oorspronklike skripsie geskryf waarop hierdie artikel gebaseer is. A.N. het dele van die skripsie bygewerk en die aanvanklike artikel geskryf, waarna albei outeurs die artikel geredigeer en verwerk het. 


\section{Literatuurverwysings}

Bennett, N., 2012, 'Spanning by soom en naat: Twee bundels ondersoek die koppelvlakte van ons tyd - albei kan gerus aangeskaf word: Vaarwel, my effens bevlekte held deur Johann de Lange', Rapport, 07 Oktober, bl. 8.

Berger, J., 1972, Ways of seeing, BBC \& Penguin Books, London.

Beukes, M., 2015, 'Johann de Lange (1959- ): Die poësie van Johann de Lange', in H.P. van Coller (red.), Perspektief \& Profiel:'n Afrikaanse Literatuurgeskiedenis, Deel 1 bl. 591-612, Van Schaik, Pretoria.

Beukes, M., 2013. 'Vaarwel, my effens bevlekte held: Johann de Lange', Tydskrif vir Letterkunde 50(2), 179-182.

Butler, J., 2006, Precarious life, Verso, Londen \& New York.

Chevalier, J. \& Gheerbrant, A., 1996, The Penguin dictionary of symbols, Penguin, London.

Cloete, T.T., 1984, Wat is literatuur? PU vir CHO, Departement Sentrale Publikasies, Potchefstroom.

Cloete, T.T., 2013, Die ander een is ek, Pooka, Plettenbergbaai.

Coetzee, J.M., 1988, White writing: On the culture of letters in South Africa, Radix Sandton.

Cresswell, T., 2004, Place: A short introduction, Blackwell, Oxford.

De Lange, J., 1984, Waterwoestyn, Human \& Rousseau, Kaapstad.

De Lange, J., 1991, Nagsweet, Taurus, Bramley.

De Lange, J., 2009, Die algebra van nood, Human \& Rousseau, Kaapstad.

De Lange, J., 2010, Judasoog: 'n keur uit die gedigte van Johann de Lange, Human \& Rousseau, Kaapstad.

De Lange, J., 2011, Weerlig van die ongeloof, Human \& Rousseau, Kaapstad.

De Lange, J., 2012, Vaarwel, my effens bevlekte held, Human \& Rousseau, Kaapstad.

De Lange, J., 2014, Stil punt van die aarde, Human \& Rousseau, Kaapstad.

Duckworth, A.M., 1991, 'Literature and landscape', in M. Coyle, P. Garside, M. Kelsal \& J. Peck, (eds.), Encyclopedia of literature \& criticism, pp. 1015-1028, Routledge, London.

Glissant, É., 1997, Poetics of relation, The University of Michigan Press, Michigan.

HAT (Handwoordeboek van die Afrikaanse Taal.), 2005, Pearson, Kaapstad.

Hambidge, J., 2009, 'Die digkuns van Johann de Lange met spesifieke verwysing na Nagsweet', LitNet Akademies 6(1), 21-41, besigtig op 05 April 2015, by http:// www.oulitnet.co.za/newlitnet/pdf/la/LA_6_1_hambidge.pdf

Hambidge, J., 2013, 'Die gesprek met die vader(s): Die Orpheus-mite in die digkuns van Johann de Lange', besigtig 11 November 2014, by http://joanhambidge. blogspot.co.za/2013/03/studie-die-gesprek-met-die-vaders-die.html

Hambidge, J., 2014, 'Stil punt van die aarde deur Johann de Lange', besigtig 03 Augustus 2014, by http://www.litnet.co.za/Article/litnet-akademies-resensieessay-stil-punt-van-die-aarde-deur-johann-de-lange

Hayward, S., 1996, Key concepts in cinema studies, Routledge, London.

Ingold, T., 2000, The perception of the environment: Essays on livelihood, dwelling and skill, Routledge, London.

lovino, S., 2012, 'Steps to a material ecocriticism: The recent literature about the "New Materialism" and its implications for ecocritical theory', Ecozon@ 3(1), 134-45.
Kemp, T. \& Forster, R., 2011, 'Deur die loergat: 'n Ondersoek na die voyeuristiese elemente in Johann de Lange se Olympia', LitNet Akademies 8(1), 185-211, besigtig op 17 Junie 2015, by http://www.oulitnet.co.za/akademies geestes/pdf/ besigtig op 17 Junie 2015, by http:/

Labbe, J.M., 1998, Romantic visualities: Landscape, gender and romanticism, Macmillan, London.

Linde, J.L, 2014, 'Eudaimoniese perspektiewe op vriendskap in Die Sneeuslaper van Marlene van Niekerk', M.A.-verhandeling, Departement Afrikaans en Nederlands, Noordwes-Universiteit, Potchefstroom.

Merleau-Ponty, M., 1962, Phenomenology of perception, Routledge \& Kegan Paul, London.

Merleau-Ponty, M., 1968, The visible and the invisible, Northwestern University Press, Evanston.

Nash, C., 1996, 'Reclaiming vision: Looking at landscape and the body', Gender, Place \& Culture: A Journal of Feminist Geography 3(2), 149-170. http://dx.doi. org/10.1080/09663699650021864

Nel, A., 2012a, 'Om 'n deeglike "aanmaning van sterflikheid" te kry: Katabasis, relasionaliteit en retrovisie in Die benederyk van Ingrid Winterbach', LitNet Akademies 9(2), 413-41, besigtig op 05 April 2015, by http://litnet.co.za/assets/ pdf/5GWNel.pdf

Nel. A., 2012b, 'By sý oë uit, by jóúne in (99): Relasionaliteit, visie en die dood in Die sneeuslaper (Marlene van Niekerk)', Stilet 24(2), 53-74.

Nelmes, J., 2003, An introduction to film studies, Routledge, London.

OSACD (Oxford South African Concise Dictionary), 2010, Oxford University Press, Oxford.

Paglia, C., 1990, Sexual personae: Art and decadence from Nefertiti to Emily Dickinson, Penquin Books, London.

Silverman, K., 2009, Flesh of my flesh, Stanford University, Stanford.

Smith, S., 2015, 'Plek as liggaam en liggaam as plek: Tendense van die nuwe materialisme en interaksie tussen mens en plek in enkele tekste uit Verweerskrif (2006) van Antjie Krog', LitNet Akademies 12(2), besigtig op 18 Mei 2015, by http://www.litnet.co.za/plek-as-liggaam-en-liggaam-as-plek-tendense-van-dienuwe-materialisme/

Snyman, H., 2012, 'Die woord leef in Vaarwel, my effens bevlekte held', besigtig 3 Augustus 2014, by http://www.litnet.co.za/Article/die-woord-leef-in-vaarwel-myeffens-bevlekte-held

Theron, A., 1989, 'Seksuele versteurings', in D.A. Louw (red.), Suid-Afrikaanse handboek van abnormale gedrag, bl. 303-340, Southern Boekuitgewers, Kaapstad.

Van Alphen, E., 1998, Francis Bacon and the loss of self, Reaksion Books, London.

Verschaffel, B., 2012, 'The world of the landscape', CLCWeb, Comparative Literature and Culture 14(1), viewed 15 August 2014, from http://dx.doi.org/10.7771/14814374.2036

Viljoen, L., 1998, 'Plek, landskap en die postkolonialisme in twee Afrikaanse romans', Stilet 10(1), 73-92.

Viljoen, L., 2009, 'Die rekonstruksie van identiteit in postapartheid Suid-Afrika: Kleur kom nooit alleen nie (2000)', in L. Viljoen (red.), Ons ongehoorde soort: Beskouings oor die werk van Antjie Krog, bl. 97-124, SUN Press, Stellenbosch.

Visagie, A., 2015, 'Johann de Lange (1959- ): Die prosa van Johann de Lange', in H.P. van Coller (red.), Perspektief \& Profiel: 'n Afrikaanse Literatuurgeskiedenis, Deel 1, bl. 613-620, Van Schaik, Pretoria.

Wylie, J., 2007, Landscape, Routledge, London. 